\title{
The Use of the New Structural Economics for Modernization and Increasing the Innovativeness of the Polish Economy
}

\begin{abstract}
Ultimately, the deciding factor for Poland's modernization success will be the pro-modernization attitude of business entities, employees, and consumers (hence, the whole society). The New Structural Economics Apparatus can be helpful in strengthening the role of the state in meeting the challenges the Polish economy is facing, but we must be aware that the application of NSE may face many serious challenges and limitations. First of all, large companies essential to create an innovative development coalition are either owned by foreign corporations or remain state property. Secondly, few Polish small and medium-sized enterprises have grown enough to be able to undertake the effort of global competition. Thirdly, the society, including business entities, is suspicious of state institutions, and the state is very distrustful about public-private projects. Fourthly and finally, Poles after years of scarcity want to consume rather than save, thus they are hardly prone to promises to improve the future standard of living in exchange for disciplined serving the interests of the state and corporations.
\end{abstract}

Keywords: Modernization; Innovations; The Role of the State; Usefulness of NSE.

\section{Introduction}

Thousands of articles and books on enterprise innovation have been written in recent decades. Schumpeter's theories have moved from the margins to the mainstream of economic considerations. In this context, the role of the state is presented as an activity supporting initiatives of business entities and scholars in the frame of the knowledge economy.

The New Structural Economics (NSE) differently distributes the accents of interdependence between the state and the economy entities - enterprises and households (or, in the nomenclature of the production function: between capital and labor). In the following part we try to show to which extent this 
approach is better adapted to the challenges facing the economies trying to catch up with developed countries, including the Polish economy as a small open economy, and to which extent this approach may face inherent difficulties.

As we have shown elsewhere, NSE recommendations cannot be directly transferred to Polish conditions. It results first of all from different long-term cultural conditions - the lack of an analogy for the tradition of social relations built on the basis of Confucianism (Jędrzejczak and Sterniczuk, 2017). An additional limitation are Poland's commitments in the legal and institutional connections of the European Union which restrict the accessibility of certain economic policy mechanisms, e.g. due to the prohibition of subsidizing companies and the requirement to comply with product, environmental, and working conditions.

However, this doesn't mean that the NSE rules and experience are unusable altogether. We see three dimensions of its use, adapted to the specific realities and challenges of the economic modernization of Poland:

1) reformulating the economic paradigm,

2) formulating and conducting economic policy,

3) participation in the global economy.

In the following part, we will discuss in more detail these three dimensions of possible application of NSE in the undertaking of Polish modernization challenges.

\section{Reformulating the Economy Paradigm}

The concept of a paradigm - the assumptions for thinking about the economy - does not seem to have much to do with the effective use of NSE in solving the problems of innovative modernization of the Polish economy A.D. 2018. And yet, quite the opposite holds true. It should be observed that the paradigm of the market economy, as we know from the theory of economics, is a product of the nineteenth Century with an admixture of legitimacy for the government's actions observed after the great crisis of the 1920s. It was then that various fragments of understanding emerged about what the market economy is, what its "clean" or proper connections with the state are and what economic policy solutions are within the accepted paradigm of the economy.

The environment of economists and economic politicians, albeit with great difficulty and reluctance, gradually allows a shift in paradigm within which it operates. This is the result not only of defending careers, but also, and perhaps 
above all, the familiarity and universality of the methodology, and therefore the language in which the group communicates.

In a nutshell, the basis (starting point) of the current paradigm of thinking about the market economy is the system of individuals, free in their choices, guided by the principle of maximizing benefits (homo oeconomicus). The free market can lead to suboptimal solutions, which however is the result of market failure and not structural (unrepairable) market characteristics. The dispute is therefore about the scale of the imperfection of the market's allocation. The existing spectrum of views begins with the position that the invisible hand of the market needs the state as a "night watch", guarding the rules of fair play between market participants, and ends with attributing the state with the roles of both the guardian of the rules of the game and the creator and administrator of economic infrastructure and the so-called strategic enterprises. ${ }^{1}$

In our understanding, NSE is a departure from understanding the economy as "market that requires more or less support from the state" for the paradigm of business entities and the state as equal partners in making economic decisions. ${ }^{2}$ This is, therefore, a thesis much stronger than, for example, the view resulting from Keynesianism about the complementary fiscal and monetary role of the state in restoring the balance of full employment.

That does not, however, mean that in NSE the partnership between the market and the state is a smooth and easy task. The problems are certainly there, but these are problems of implementation, not of principles. NSE promotes the point of view that with the challenges faced by the so-called catching up countries, the limitation to just the "market or state" discussion, rather than leading to any good solutions, is pure waste of intellectual potential on false disputes and of material resources on creating and implementing unrealistic solutions.

It should be emphasized that this perspective is qualitatively different from the proposition of the dominant role of the state (e.g. Mazzucato, 2013), which is nevertheless a position in the dispute on the market or the state.

1 Extremes: (a) the total elimination of the market, after years of futile attempts by communist countries, found its well-deserved place in the dustbin of history, and (b) the market without a state found its shelter on the Internet.

2 NES does not devote significant attention to households as subjects of economic decisions (as is the case in mainstream economics derived from the classical paradigm). In our opinion, this does not result from neglecting households decisions regarding behavior on the labor market and the level and structure of consumption, but it has pragmatic reasons - the ability to shape households behavior requires a lot of time (almost a generation) and the results are still uncertain. In addition, NES is a proposal for catching-up countries, where "hunger for work and basic consumer goods" is dominant in the households decisions. 
The paradigm of the NSE economy, assuming a partnership of entrepreneurs and the state, first had to assume that both sides are equal to a certain extent. Paradoxically, this means not so much the strengthening of the state as that the state is willing to self-restrain its instruments. This is a concept referring to the history of Japan's development, and later to South Korea, and is currently being implemented in China.

Forms of partnership could be found in the activities of the government development coalition and chaebols in South Korea or the government and private corporations in the development of Japan in 1946-1970. In both cases, this partnership was operating in the context of a culture that is the heir of Confucianism, where the liberal, western concept of partnership as co-operative actors is simply unimaginable, especially in the traditional societies of these countries. However, one cannot fall into the trap of applying Western thinking about the domination of the state based on instruments of administrative coercion. In both Japan and Korea, it was communication between the state government and free private business entities. For example, maintaining a separate opinion or even aversion to the actions recommended by the allpowerful Ministry of International Trade and Industry (MITI) in Japan did not pose a threat of losing one's position, let alone losing the ownership of a private enterprise. It was similar in South Korea. This prevented, among others, the accumulation of errors in economic policy and selected directions of enterprise development.

A good illustration of this dependence is the relationship between the government and business entities in Japan in the 1950s. Well, at the beginning MITI was against the development of the car industry and electronics. Trucks, construction machines, elementary household appliances were accepted while private passenger cars or sophisticated electronics were not. However, the business stubbornly pursued its goal and after many years this rebellious concept was accepted by MITI, although at the beginning the stream of government assistance avoided these "invalid" businesses. As we know, the effect of this direction of development was the achievement by Japan and then Korea of dominant position on global markets.

The partnership between the state and the corporation is difficult to enforce because of the difference in weight of the two actors: the state may ultimately appeal to its monopoly of "the use of violence". Nevertheless, when the state sees a partner in a private corporation, respect for private property sets the boundary of forced development concepts. In this case, if MITI had more control, we would probably have neither Sony nor Japanese cars or at least their creation would have been seriously delayed. Partnership means both cooperation 
and dispute, and ultimately the possibility of breaking the relationship. This creates a healthy principle of the necessity of analyzing the partner's perspective and justifying one's position and thus enforces a compromise. These processes enable mutual adaptation and creation of new solutions that are closer to the options appreciated by the partners.

In this context, China's experience is extremely interesting for the global economy. Due to the historical legacy of an extremely nationalized economy, we are now dealing with deliberate "farming" by the state of private corporations that may become partners in the modernization program.

In conclusion, next to the state as the founder of economic policy and the controller of its implementation through ownership and similarly drastic forms as well as the state as a night guard, there is a place for the state as a private business partner. This concept, however, requires meeting two elementary conditions: on the part of the state - accepting the fact of partnership with autonomous entities able to calculate their business interests, and thus respecting these calculations, while on the part of business - accepting responsibility for the economic development, i.e. a system that goes beyond the narrow interests of a single business. This is what happened in Japan and in South Korea. In both cases, we were dealing with the formation of a business and state development coalition. In both cases, they managed to convince the rest of their societies to accept this coalition and a high level of savings, which allowed for a high investment rate.

\section{Formulating and Implementing the Economic Policy}

The goal of the NSE is that of "assisted convergence" - actions aimed at catching up with highly developed, affluent Western countries by countries aspiring to join this exclusive club.

Historically, neither the theory nor the practice of catching up is a new phenomenon, as exemplified. among others, by Rosenstein-Rodan (1943).

One historical example of a successful state-run modernization is Prussia of the early nineteenth century, which can be considered as the pioneer's formula for a centrally managed comprehensive reform, as says one of its creators, based on the "three-dimensional primacy: army, knowledge, and constitution" (Gneisenau, after: Nipperdey, 1998).

However, as revealed by the economic history successful convergence through modernization unfortunately happens rather seldom. In the modern world, 
convergence is more difficult than it used to be in the historical past. Nowadays, more than accelerating the growth by using inactive labor resources ${ }^{3}$, it means modernization of the economy through the allocation of active resources to activities with higher added value. In the first place, it is a challenge of "passive modernization" consisting in adapting solutions taken from the West. In the second one - it is a challenge of "active modernization" based on the creation and implementation of original proprietary and innovative solutions.

The reasons for the successes but also failures of modernization programs can be found both on the side of the structure of the modernization process and the practice of managing the process. ${ }^{4}$

\subsection{Structural Determinants of the Modernization Process}

On the side of the structure of the modernization process, the basic problem is that of an inevitable tension between the "political cycle" and the "modernization cycle". While the political cycles in democracies operate within perspective of a few years, "from elections to elections", modernization cycles are carried out in perspective of a dozen or so years determined by a significant increase in the share of the economy based on innovative products. Systemic modernization, i.e. based on mass innovations (rather than innovations introduced ad hoc, no matter how successful and spectacular) requires long-term measures sufficient to carry out and "root" institutional and regulatory changes that determine the effective transfer of knowledge to the economy, as well as the internalization of relevant participant behavior. Hence the temptation among the catching up countries to sacrifice democracy for modernization. The case of China also introduces a historical precedent in this respect. Only a few decades ago, the prevailing view was that Western political democracy is a prerequisite for modernization, but China's current modernization successes have undermined this argument. Of course, in the case of Poland, even for reasons of international obligations, such a dilemma is not present, although an acceptable model of democracy, due to individual solutions of the implemented practice, is quite capacious.

In this context, declarations of politicians, but also of entrepreneurs and managers, that innovations - especially based on native knowledge - are worth

3 Although it is also important especially in populous China and India, and in Africa in perspective of decades.

4 It should also be remembered that specific historical cases of success or failure also depend on many uncontrolled factors, such as the leader's personality, breakthrough political or technological events, external threats. Such phenomena, albeit undeniably important, are not considered here. 
unconditional support, are suspicious. Innovation means the disruption of the status quo on many levels. Innovation causes greater or lesser distortion of the economic and social order for many social groups, at least in the short and medium-term.

From the point of view of the state, particularly distortive impact of innovation occurs on a politically sensitive labor market. Therefore, the phenomenon of "killing innovation" by the state policy of protection of jobs in the old sectors of the economy is a reaction justified by the political cycle. First, trade unions in the old sectors are well embedded in political structures. Often, the occupations of declining sectors are perceived high in the social gradation of occupations (in Poland, such is the profession of a miner). The new and innovative sectors are deprived of such advantages - by definition they offer few jobs and, worse still, they often pose a threat to jobs in the old sectors of the economy.

The success (or not) of the social process of modernization through innovation is entangled in circular dependence of a "vicious circle" character: innovations are the engine of development, but in order for innovation to become a driving force for growth, it is necessary to achieve a sufficiently advanced level of economic development. As a consequence, the modernization challenge at the structural level is a shift from a low-potential innovation economy (Fig. 1) to the economy of high innovative potential (Fig. 2).

Figure 1.

A low innovation potential economy cycle

\begin{tabular}{|c|c|}
\hline $\begin{array}{l}\text { Simple low-paid job } \\
\text { combined with high } \\
\text { unemployment } \\
\text { and low level } \\
\text { of professional activity }\end{array}$ & $\begin{array}{l}\text { Low internal } \\
\text { demand and high } \\
\text { job insecurity, } \\
\rightarrow \quad \text { low demand for } \\
\text { products and services } \\
\text { with a high knowledge } \\
\text { content }\end{array}$ \\
\hline 4 & $\downarrow$ \\
\hline $\begin{array}{l}\text { Fixation of an extensive } \\
\text { economic model until } \\
\text { the surplus of simple } \\
\text { and cheap labor is } \\
\text { exhausted }\end{array}$ & $\begin{array}{l}\text { Lack of motivation } \\
\text { for innovation: } \\
+\quad \text { low expenditure } \\
\text { on } R \& D, \text { small capital } \\
\text { investments (machines } \\
\text { and personnel) }\end{array}$ \\
\hline
\end{tabular}

Figure 2.

The high innovation potential economy cycle

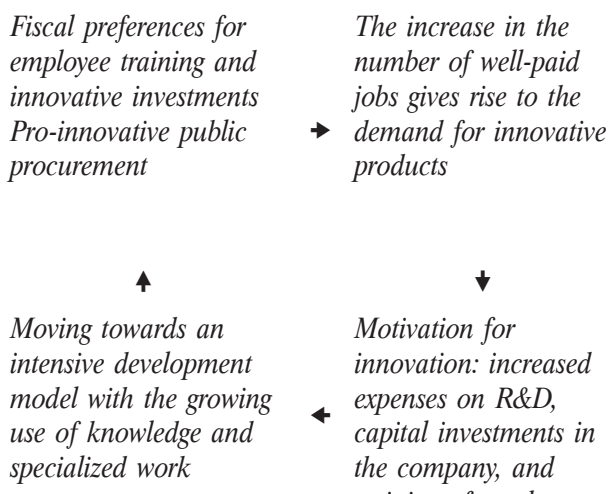

$\rightarrow$ demand for innovative products

Moving towards an intensive development model with the growing use of knowledge and specialized work

Source: own study

The transition from the cycle of low innovation potential to the cycle of high innovation potential requires time and changes, both economic and socio-political. For the continuation of these efforts to be viable in an 
uninterrupted political cycle, a consensus of political and economic elites is essential. An example of the development of South Korea shows how important such an agreement is.

The agreement of the political and economic elite was initially enforced in that country by the dictatorship of General Park, but later it became quite broadly accepted which continues to this day. In Korea, the transitional period covered six 5-year development plans. Until mid-1970s it was driven by cheap work and later, by the mid-1990s., by investments. The period of building the potential was crowned in 1996 by the membership in the OECD, and then by an intensive focus on innovation (U.S. Bureau of Labor Statistics, 2018).

Often, the level of research and development (R\&D) expenditure is assumed as condition for the transition from the low innovation potential cycle to the cycle of high innovation potential. These expenditures are obviously a prerequisite for a successful transition. However, from the point of view of modernization policy, the structure of expenditures (share of state and private participants in the research sector) and absorption of innovation by industry are of fundamental importance. The strategy of enforcing innovativeness by significantly increasing the state's expenditure on $\mathrm{R} \& \mathrm{D}$, although it brings certain results, is still largely wasted.

Looking from perspective of the experience of countries that have emerged from the group of aspirants and gained lasting presence in the group of leaders in the innovative economy, it seems that the transition from a low-potential economy to a high-potential innovation economy requires proper ordering of several important issues:

- minimizing the tensions between the political cycle and the time necessary to obtain developmental effects through the agreement of political and economic elites and agreeing on a long-term strategy;

- major investments in R\&D, probably at $2.5 \%$ of GDP and state-supported development of research potential in corporations; it is the focus upon the application that allows for accelerated effects of scientific research;

- development of an education system focused on creativity, science, technology, and cooperation between people;

- mobilization of society, public opinion, towards the development of innovation in public life and economy; this requires a serious propaganda effort, institutions, and financial outlays. ${ }^{5}$

5 This extremely important problem goes beyond the scope of this chapter. It is worth, however, to signal the key meaning of the so-called Sputnik moment - mobilization of the United States in the face of the launch of the Soviet Sputnik into the orbit. 


\subsection{Practice of Managing the Innovation Process}

A high percentage of unsuccessful modernization attempts, in our opinion, results from excessive focus on "what to do?" question, instead of giving the right answers to the "how to do?" question.

The former question not only seems to give priority to one's intentions versus one's capacities, but also inevitably leads to multiplication of tasks by interest groups, bureaucracies, and politicians. In essence, this practice is not really different from the practice of "attaching to the plan" known from the planned economy. Such an operation is greatly facilitated by the fact that numerous tasks can be justified as being socially and economically important (which they actually are, in most cases). As a result, the modernization program enjoys wide support, but has little chance of being implemented, due to inadequate material and human resources.

The question "how to do" requires a critical in-depth assessment of the available opportunities for a specific country at a given time. The difficulty of answering it lies in the fact that the range of possibilities is narrower than the scope determined by the "what to do" diagnosis so it requires reducing the number of priorities, thus violating the expectations of some interest groups.

The first step towards "what to do" is a realistic assessment of the country's place on the global map of competitiveness in relation to other countries building their advantage on innovation rather than on low costs. The current position on the global map of competitiveness and the chances of promotion need to be assessed realistically. Speaking colloquially, in which league the country is currently playing, and in which it could play in a few seasons, climbing up or falling down in the rankings, has to be assessed.

The value of even the best-conceived and socially accepted modernization program is determined by how it is implemented, and this in turn requires a proper continuum of human resources - from the broadly understood apparatus of the state, through local governments, to the organization of civil society.

The efficiency of the apparatus is decisively determined by its stability and de-politicization of officials elected on the basis of merit and integrity criteria. The importance of the official apparatus of the state in economic management is particularly important, but also rather complex in the case of the implementation of innovation policy. In the case of staff implementing innovative policies, the assessment of the effectiveness of the clerical staff is more difficult than in other areas of the state's activities, due to the "poor algorithmicity" of such an assessment and a significant time gap between the actions and their effects. There is a fundamental contradiction between the 
characteristics of good administration - dealing with standard rules and risk avoidance - and innovations which, by definition, have to boldly challenge the existing order and are burdened with significant and poorly defined risk. Hence the temptation to evaluate based on the implementation of outlays, e.g. spending state money on $\mathrm{R} \& \mathrm{D}$, can lead to a waste of resources and, worse still, the creation of "Potemkin villages" giving false sense of success.

The creation of an administrative staff meeting these conditions is only the first step. In an efficient administration system, the behavior of officials is largely shaped not by their personal qualities, but by the institutional environment - a system of rules and motivations that trigger or prohibit certain actions. Rules and regulations, formal and informal, together define the structure of the incentives of officials in a particular organization or in the public sector as a whole. The area of innovation policy requires officials to go beyond the standard range of expected personality traits - here a component of businesslike attitude is required, e.g. the ability to take risks and accept the reduction in time of the role of administration in a given area.

Administrative efficiency studies show that regardless of the state, at the level of individual motivations, to perform their duties well (in the understanding of system expectations), officials must see the connection between their effort and the future evaluation of their work. The durability and consistency of these relationships are shaped by the institutional environment in which they work (Manning, Mukherjee, and Gokcekus, 2000). However, the relationship between the behavior of officials and the institutional environment is not deterministic. In the same environment some clerks work inefficiently (although this is generally a learned inefficiency, not the result of their inherent ineptitude), some use their position to obtain side incomes, including corruption, others work efficiently, with public interest as a priority. Therefore, we can talk about the prevalence of certain behaviors in a given environment rather than an allencompassing rule.

Knowledge of the conditions for the efficient functioning of the administration does not automatically translate into the ability to reform the administration itself. The World Bank estimates that less than half of the projects supporting administrative reforms have been successful. Among the reasons for such a low effectiveness of interventions aimed at introducing more efficient and more suited to the needs of modern public management systems, the World Bank points to a too narrow, technocratic point of view on what is needed in public sector reforms and reliance on "best practices" transferred from developed countries, and often impossible to implement in developing countries. A condition for improving the efficiency of public administration reforms should be "working 
with local partners to better understand and take into account a wide range of motivations and pressures - both within and beyond the authorities - that affect the functioning of public administration" (Manning, Mukherjee, and Gokcekus, 2000, p. 1).

The problem of key importance is the functional relationship between the world of politics (government) and the world of administration (management). The political attractiveness of clientelism and the threat of corruption in the areas of public procurement, state subsidies, division of seats in state and local government organizations causes that the creation of a "Chinese wall" between the administration and the world of politics is of special importance. This applies to state administration, but perhaps it does even more to local government administration, where the boundary between governance and management is fluid (World Bank, 2008).

The traditional method of separating administration and politics is to create civil service. This concept relies upon two pillars: substantive competence and occupational stabilization. Such elected civil servants are loyal to the interest of the state over the current interests of the ruling party.

Historically, the choice of civil service in the transformation countries, including Poland, required addressing the problem of "original sin" - stabilization of the first generation of civil servants - that is, people coming from a system that proved to be out of order. At the beginning of the transformation, there was a risk of stabilization of officials who not only were shaped under the failing system, but also quickly losing their substantive qualifications (we ignore the matter of loyalty to the new political order). ${ }^{6}$ In addition, the acceleration of changes in the economy and society leads to an additional problem of the functioning of the civil service - a rapid depreciation of the knowledge of officials. The "mandarin administration" model was adequate for management in a stable environment. In times of rapid change, misunderstanding of new technologies and social behaviors and trends may even lead to obstructive, anti-innovative activities.

6 Historically, this problem has been solved in various ways. For example, in Great Britain there was a landed gentry class, which, thanks to the principle of the indivisibility of landed estates, "shoved out" people well-prepared to the civil and colonial services. In continental Europe, civil service was the instrument of exercising the power of the "enlightened" absolute monarch. These systems have also been appropriately transferred to former colonies. A specific model was adopted by classical China, where the substantive factor of the selection of officials regardless of the class was dominant (famous exams of the knowledge of thousands of writing characters). However, in no historical case, the civil service class was created in a democratic environment of power. For this reason, the United States bases the administration on the civil service on a much lesser scale than other Western countries, and much more on political nominations. 
The undoubted weakness of the Polish administration is the lack of civil service, that is, the official class chosen according to substantive criteria and not subject to exchange with the change of the ruling party. The successive governing parties sought to exchange the civil service for loyalty to politicians, manipulating the statutory grounds of the civil service, e.g. by introducing the principle of "fulfilling duties" or by resigning from the principle of competition recruitment. The need to reward the party allies and common nepotism were not without significance. "Every government - contrary to the rules of the civil service - prepares and pushes its bill for itself, but when it starts to implement it, the government already has to give its place to the next one. You can say that each of them makes the bed for the next one to lie in... Citizens are victims of constant atmosphere of danger and uncertainty" (Górzyńska, 2009, p. 198). Unfortunately, this opinion is still valid.

In the case of Poland, the difficulty of building an administration capable of managing the innovation process must be confronted with the fact of unprecedented growth, in the last two decades, of the number of university graduates of the majors required in efficient administration: economics, law, management and administration. During the initial period of transformation, the option of working in administration was losing with the opening possibilities in private business, much more attractive both financially and socially. The improvement of the general standard of work in administration and the increase of competition on the private market caused that "work in the office" becomes a considered alternative for young university graduates. This confirms the thesis about the politicization of employment in the administration, but also in the commercial companies under the direct control of the government and local governments. Having access to educated graduates, the Polish political class does not have to build from them an efficient, politically universal official apparatus.

The progressive shifting of the center of gravity of innovative activities from the space of individual activities at the connection between science and enterprise for activities into the social space requires a new type of partner for state administration in conducting pro-innovation policy - an as wide and diversified as possible range of civil society organizations: from associations of producers, through independent research centers (think tanks), to charities. The experience of highly developed countries confirms the growing development role played by non-governmental organizations, in particular as regards:

- intermediation between the administration and citizens - on the one hand, as to the transmission of aspirations, questions, and proposed civic alternatives, and on the other hand - as to the transmission of government intentions and actions in a manner comprehensible to citizens; the function of "translating" 
the intentions of the economic policy administrator will become increasingly important as more and more areas of economic policy cannot be assessed directly by citizens and require a professional but independent evaluation;

- social control of administrative activities (accountability) as to their transparency and use of funds;

- providing services such as training, eligibility of policy beneficiaries, etc.

The tissue of social organizations in Poland is still underdeveloped. Such activity is still associated by Poles more closely with Stefan Żeromski's protagonists than with a systematic and pragmatic contribution to their environment, which does not require dramatic life sacrifices.

A richly structured civil society with a dense network of non-profit organizations that support the diversity of society is a property of Protestant culture (we are aware of serious simplification in this assessment). The undeniable cause of poor development of systematic activities of social organizations in the transformation years was the emergence of opportunities to improve the well-being of their family and loved ones through increased professional effort, directly competing for the same time budget with activities for "strangers". There was also the possibility of occasional charity activities (such as WOŚP [The Great Orchestra of Christmas Charity]), a positive phenomenon in itself, but giving people justification for poor participation in social organizations. Undoubtedly, bad experiences of pseudo-social organization of Communism has also played a role here. Yet another dimension of this phenomenon is the durability of cultural features.

Social activity supporting modernization activities has been on a similar level for several years without any upward trend. About $1 / 3$ of society is active. In volunteering, $1 / 5$ is involved in formal organizations, and about $1 / 4$ of the population in actions for people outside the circle of family and friends or for the benefit of the neighborhood ${ }^{7}$ (Adamiak, 2014).

\section{Participation in the Global Economy}

In the foreseeable future, we will be exposed to ever more brutal competition in the globalized economy, both for resources and for outlets. This is primarily

7 The percentage of respondents declaring their involvement in volunteering for a charity organization is probably high, as some of the respondents were able to consider material support for these organizations as volunteering. 
influenced by the geopolitical factor - the extension of the competition area to supply resources and markets from countries that are not yet significant entities of the global economy. The geopolitical factor is revolutionarily strengthened by new technologies that reduce the transaction costs of moving people, goods, and information, and thus allowing the creation of global flexible production chains - new rules for capital allocation.

\subsection{Poland in the Face of the Challenges of Global Competition}

Under the new conditions, competition methods will change, which will give Poland the chance to improve its position in the global economy. So far, the development based on producing more of the same, in the best case with a change in technology leading to a reduction of costs, was the dominant development strategy. In the Polish economy there were serious technological and organizational changes, the carrier of which were new production methods implemented to companies by new, generally foreign business owners (privatized and greenfield). Technological and organizational innovation did not result from original Polish inventions or the pressure of Polish entrepreneurs to implement them. It took place as a result of the absorption of technologies and organizational solutions invented outside Poland; as a rule they were innovative imitations in relation to foreign parent companies.

In general, foreign business owners retained well-prepared employees, the product market as well as the product brand, and then modernized the production process by introducing new machines, perfecting product design and marketing. It was a passive process of injecting innovation into the economy. An example may be the dairy products market, where the old names and flavors of products often hide the new technology of their production, obtaining raw materials and distribution - thus reducing costs, including those of employment.

The autonomous demand for innovation was related to the somewhat organic response to the inefficiency of the planned economy system. During the transformation, Poland experienced a real explosion of small businesses, a phenomenon widely admired in the world as a proof of the natural need for economic self-realization in a market economy. Transformation has created enough space for a group of enterprising people going into millions. New entrepreneurs, when establishing small companies, were inevitably buying new machines and technologies, more efficient compared to previously existing ones, even if they were second-hand after several years of use in the west. In Polish conditions, it was still a huge innovative leap (just like a five-years old Mercedes is still much better than a brand-new Lada). 
The modernization based on "filling in the gaps" inherited from the past obviously has its limitations - its causative power lapses with the removal of the old system's malfunction.

The current modernization only gave an indirect strengthening of the competitiveness of the Polish economy - replacement of imported products with local ones. ${ }^{8}$ However, it failed to create the potential for competing on global markets. The development by entering higher levels in the product value creation chain and changing the structure of the economy by increasing the share of sectors with higher productivity and uniqueness is of course the best way to modernize, giving the greatest opportunities for productivity growth and competitiveness in the dimension of not only individual enterprises, but also the entire economy and society. Unfortunately, and despite the progress of recent years, this is still not very much the case of Poland.

\subsection{NSE Against the Challenges of Global Competition}

The great temptation of state modernizers is economic protectionism. This applies both to the protection of old industries and the infant industries. While such a model of modernization could make sense in the $20^{\text {th }}$ century, it no longer does (and more importantly, it has become short of instruments now) in the era of free trade and the emergence of innovative product substitutes. ${ }^{9}$

NSE protagonists are aware of the failure of the state's modernization activism based on protectionism. In particular, lessons were learned from the failure of the import substitution policies, popular in Latin America in the 1960s and 70 s, which consisted in supporting domestic producers offering products replacing imported products. This policy, justified by the desire for accelerated modernization, has had effects opposite to expected. Despite short-term benefits, such as increased employment and the creation of a limited number of better-

8 An example of this is the repression of foreign food products, en masse entering the Polish market in the early years of transformation, by Polish products, thanks to their increased attractiveness.

9 The drama of America first protectionism or the French defense against "social dumping", which unfolds before our eyes, can have far-reaching consequences for the program of innovative modernization in countries such as Poland. Symptomatic was the reaction of E. Macron on the plans of Whirlpool companies to transfer production from France to Poland. "Macron talked to the regional daily of Northern France after Wednesday's meeting in Amiens with workers on a strike of Whirlpool factory, which will be closed due to the relocation of production to Łódź [...] Within three months after choosing me (for president) a decision will be made on Poland”, said Macron. Acquired from: https:/www.bankier.pl/ wiadomosc/Francja-Macron-opowiea-sie-za-sankciach-wobec-Polski-3685431.html. 
paid jobs, the lack of competition led to low innovation and low productivity, and consequently to high prices with poor quality of local products compared to imported products. Moreover, the discretion of protectionism led to increased corruption and deepening income inequalities (Lustig et al., 2013).

Therefore, NSE postulates the implementation of a modernization program within the framework of an economy open to competition challenges on a global scale, even using its mechanisms and economies of scale. This is a proposition based not on the zero-one game, but on the activities with benefits for all participating parties of the agreement. This, in turn, requires coordination and cooperation at the state level. An example of such coordination is to be a crossborder program of the so-called New Silk Road.

The integrating argument underlying the benefits of such coordination between states is supposed to be a similar relationship of catching up countries in relations with highly developed countries - their peripherality.

In the relationship between the center and the periphery, the type of investment or, more broadly, the international division of labor is of a structural nature. Foreign direct investments in catching up countries from Western countries are generally concentrated in traditional sectors with a low degree of investment risk, and thus of low saturation with innovations. Foreign investments reach sectors with significant energy consumption and for environmental reasons not tolerated in developed countries, such as cement plants or steelworks and assembly plants that use cheap labor (we should not confuse the assembly of high technology products with innovations). Attempts to motivate foreign investors to invest in innovative projects, e.g. by tightening environmental regulations, may lead to consequences opposite to those intended - limiting the inflow of investments to traditional sectors and escape to countries ready to accept the conditions set by investors.

Limiting the transfer of innovation from the top shelf to the peripheral countries has its rational business basis. In the first place, it may be dictated by weaker workforce preparation and lower externalities than in the countries of origin. Although the workforce in Poland may have (and often has) a higher formal education than the workforce in developed countries, the practical knowledge (tacit knowledge) is decisive for the investor, and it is gained practically by imitating the masters of the profession and by participating in the employee group. It is difficult to transfer between countries or communities and is acquired over years. The requirements of practical knowledge are the more common and easier to obtain, the lower is the activity technologically located in the production chain. 
The strict environmental and labor standards in developed countries are an important reason for the transfer of business elements that do not meet them, to countries willing to accept less stringent standards. The motive of the location is therefore the possibility of externalization of costs related to compliance with standards. This applies to a significant extent to „dirty” elements of the production chain, usually with the lowest saturation with high technology and the least innovative ones.

The fact cannot be ignored that the latest, most innovative products and technologies determining the competitive advantage are under the strictest protection of the enterprises that produce them. Therefore, they look with great suspicion on proposals for improvements proposed by subcontractors from peripheral countries - the risk of losing the monopoly in the field of product improvement is often reckoned greater than potential benefits resulting from the possibility of cost reduction.

In the reduction of the center-periphery innovation flow, non-business factors also play an important role. Foreign corporations, in the event of global demand constraints, are under great political pressure - to which they often succumb - to relocate production ranked high in the value creation chain from the peripheral country to the investor's country of origin. The issue of the so-called nationality of capital, or rather the submission of foreign owners to the political pressures of their countries of origin, returned with increased strength in the aftermath of the 2008 crisis. The effect of liquidation, in the peripheral country, of production with high saturation with modern innovative solutions is the unfavorable change in the structure of the economy into less innovative and the reduction of the pool of well-paid jobs. In the long-term, this means liquidation of places where employees can acquire practical knowledge, which adversely affects the social capacity to build innovative potential in the entire economy.

\section{Conclusions}

Modernization of the economy means moving to a model that allows obtaining significant revenues from participation in the global economy at a higher level of value chain within the existing sectors of the economy and changing the structure of the economy consisting in increasing the share of sectors with higher productivity and better global competitiveness.

This task is not easy. The results depend to a large extent on the ability to launch the social ability to innovate as a systematic activity aimed at better 
use of available resources and better meeting the needs, this depends on the ability to cooperate - establishing developmental coalitions between the state and enterprises. In this context, the question must be asked, with whom from the sphere of business in Poland in the coming decades can the state create a development coalition?

The Polish economy is dominated by micro-enterprises employing up to 9 people (96\% of the total). The Polish economy has only about 3,500 (0.2\% of the entire collection of non-financial sector enterprises) of large enterprises. The sector of large enterprises is dominated by state-owned companies and companies controlled by foreign capital. Among the 10 largest companies (by sales volume), $54.9 \%$ are revenues of companies controlled by the state. Among the transformation countries, a larger share of the state-controlled sector is only in Ukraine (68.9\%) (Szarzec, 2016, p. 130). The average employment in companies controlled by the state is 243 employees, by foreign capital 230, and by domestic capital 72 people. The sector of large companies controlled by domestic capital essentially does not increase, while the sector of statecontrolled companies grows up (Błaszczyk, 2017).

Small and medium-sized enterprises, although they constitute the core of the Polish economy in the sense of the proportion of employment and contribution to GDP, have neither enough capital nor human resources to actively participate in the research and development market. On the other hand, the sector of state-owned enterprises, in spite of including large enterprises, has only $8 \%$ of export revenues, which means the lack of strong competition on the market, which verifies the innovative potential.

Foreign companies in Poland play and in the foreseeable future will continue to play a significant role in introducing innovations to the Polish economy - both capital and non-capital. Therefore, Poland's attractiveness for foreign investments should be maintained as they are major source of inflow of new products, technologies, and methods of organization and management from the outside. Foreign companies can and should be treated as an important source of innovation for Polish cooperating companies. However, this requires skillful support from government authorities, which, as shown by technology transfer associated with the purchase of Western weapons, is not a simple task.

However, it must be realized that such a strategy means the dominance of imitative innovations that are generated and installed by Polish contractors as part of production tasks commissioned from globally-operating mother companies. Non-sovereign innovations involve two types of risk. Firstly, such innovations may be withdrawn from Poland in the case of moving production to locations more profitable from the point of view of the parent company. Secondly, 
non-sovereign innovations, generally embodied in imported machines, do not develop local innovation potential, for example, through reverse engineering (in Poland impossible for many reasons), which lay at the basis of the initial success of the Far East countries.

An increasingly popular area of economic activism of the state is supporting startups, especially in fashionable areas such as biochemistry or IT. This is an important activity, for instance for triggering the "social innovation energy", popularizing success based on talent and knowledge as the main driving force of modern economies. However, it should be remembered that for a transition from startup to implementation, you need a whole business ecosystem, which, unfortunately, is lacking in Poland. Therefore, by increasing the state's involvement in the development of startups, their significant impact on the economy should not be expected.

The direction of the modernization development coalition, in which the current government has the highest hopes, but which is also the most controversial, is the use of large ventures (companies) controlled by the State Treasury. The explicit justification is that only these "non-limit" companies have significant capital resources necessary to implement capital-intensive modernization programs (such as the central airport). The implicit justification is the ease of "convincing" the management of these companies to invest in selected programs. In the case of SP companies, it is a natural instinct to appeal to administrative and political domination, only formalistically hidden under the guise of ownership interventions. This accusation is even more relevant to enterprises controlled by local governments, where the temptation of nepotism and corruption is stronger due to weaker social control. ${ }^{10}$

The successful use of capital resources of SP companies in the process of modernization of the economy requires a combination of: (1) selection of management personnel based on purely substantive criteria; (2) compliance with good corporate governance, in particular exclusion of interventions "on the phone"; (3) a professional external evaluation system (audit) of companies.

As a result of these restrictions, in contrast to the Asian examples of success, in Poland the policy based on the NSE suggestions has no obvious candidate

10 In the Polish legislation, the construction of the SP company appeared in the privatization law of 1990 (which the authors co-created). The original intention was to give large state enterprises "in line for the privatization" a market form. From the perspective of the years, this was naive thinking, underestimating the political interests around these companies. However, the alternatives were also flawed. This was shown by the privatization in both Russia and Czechoslovakia. 
for creating a development coalition. This is the most serious limitation of this concept as a suggestion for creating catching up strategies.

In this context, a better balance of economic activity by strengthening cooperation with other catching up countries makes sense. In the first place, strategic pragmatism recommends presence on a maximum possible number of markets, especially during far-reaching changes in the global economic order. The Polish economy is to a significant (in our opinion excessive) degree dependent on the German economy ( $1 / 4$ of exports). This is particularly important with the expected export opportunities in the Asia-Pacific region markets, which are becoming the most dynamic region of the middle-class growth and related demand. In 2015, consumer spending (PPP, in USD 2011) of the US accounted for USD 4.7 trillion, which accounted for $13 \%$ of world consumer spending, and for China it amounted to USD 4.2 trillion, which accounted for $12 \%$ of world consumer spending, for Germany respectively USD 1.5 trillion and $4 \%$ of global expenditure. The forecasted figures for 2030 are: for US, USD 4.7 trillion and 7\% of world consumer spending, for China USD 14.3 trillion and 22\%, Germany USD 1 trillion and 2\% (Kharas, 2017).

One should, however, be aware that Poland's modernization aspirations may interfere with the interests of the economies and companies of both the center and the periphery; both at the strategic level and in specific cases. The model of participation in the global economy has so far been implemented through relations with the investors of the center. NSE, with its redefined role of state and national interest, on the one hand leads to a redefinition of cooperation with traditional Western partners towards greater selectivity and investment conditions (e.g. tax holidays). On the other hand, it requires new skills in running economic policy under the conditions of a different culture of cooperation and asymmetry of the potential of partners. ${ }^{11}$

Polish companies are beginning to enter the global market, where they are under a great competitive pressure, rewarding technologies and the latest products. Therefore, there are not many such companies, but there are many companies that cooperate with the largest global corporations operating on a global scale. This is the case even in the car industry. These co-operators are also under pressure: searching for new methods of management, production, employee training, improving quality. Indirectly, just like the companies for whom they work, they compete on global markets. This fosters complementary innovation. This mainly applies to the growth opportunities of medium-sized

11 Symptomatic is the " $1+16$ " formula of cooperation between China and 16 countries of Central and Eastern Europe - the population of " 16 " is less than $10 \%$ of the population of China. 
companies with Polish capital and original Polish products and technologies. A question arises about an extent to which the state can consciously "breed" large companies based on Polish capital? It seems that the use of the oligarchic patterns from Asia would encounter a barrier of social distrust having its origins in creating fortunes in times of turbulent transformation. These fortunes were too often created as a result of unclear relations between the state apparatus and businessmen (although in Poland these practices were much less frequent than in the former USSR).

Ultimately, the deciding factor for Poland's modernization success will be the pro-modernization attitude of business entities, employees, and consumers (hence the whole society). The New Structural Economics Apparatus can be helpful in strengthening the role of the state in meeting the challenges facing the Polish economy, but one should be aware that the application of NSE can face many important challenges and limitations. First of all, large companies needed to create an innovative development coalition are either owned by foreign corporations or remain state-owned. Secondly, not many Polish small and medium-sized enterprises grow large enough to undertake the effort of global competition. Thirdly, the society, including entrepreneurs, is suspicious of state institutions, and the state is very distrustful about public-private projects. And finally, fourthly, Poles after years of scarcity want to consume and not save, thus they are not prone to promises to improve the future standard of living in exchange for disciplined serving the interests of the state and corporations.

Therefore, further modernization of the Polish economy will be the resultant of social, political, and international constraints as well as developmental motivations of society. In the system of international circulation of goods, services, money and people, a series of adjustments awaits us, the nature of which is difficult to predict today. The main internal challenge is the secular demographic change: the aging of society and the decline in professional activity. Paradoxically, the transition to the employee's market may prove to be a strong motivator for entrepreneurs for labor-saving technological innovations and management.

Individual consumer motivations in Poland are very high, while motivations for creating forms of co-development with the state of the development policy seem insufficient. The result is the domination of the state in the articulation of goals and directions of development, with weak participation of economic and social entities. For a country wishing to pursue a more active economic role in accordance with the recommendations of the New Structural Economics, this may mean a trap of erroneous, because not externally evaluated, economic policy priorities, as well as the selection of inappropriate methods and people 
to implement them. "Pride goes before destruction, a haughty spirit before a fall." This wisdom of King Solomon should hang over the desk of every NSE policy official. ${ }^{12}$

\section{References}

Adamiak, P. (2014). Zaangażowanie społeczne Polek i Polaków. Wolontariat, filantropia, 1\% $i$ wizerunek organizacji pozarzadowych. Raport z badania 2013. Warszawa: Stowarzyszenie Klon/Jawor.

Błaszczyk B. (2017). Zmiany w systemie instytucjonalnym polskiej gospodarki. Wypieranie własności prywatnej rynku przez państwo w ramach „Dobrej Zmiany”. In: W. Gadomski (ed.), Raport: Perspektywy dla Polski. Polska gospodarka w latach 2015-2017 na tle lat wcześniejszych i prognozy na przysztość. Warszawa: FOR. Acquired from: perspektywy. for.org.pl/wp-content/uploads/2017/11/Raport_Perspektywy_internet.pdf.

Górzyńska, T. (2009). Służba cywilna w Polsce: Problemy z tradycją, problemy z przyszłością. In: J. Supernat (ed.), Między tradycją a przyszłością w nauce prawa administracyjnego. Ksiega jubileuszowa dedykowana Profesorowi Janowi Bociowi (s. 189-199). Wrocław: Wydawnictwo Uniwersytetu Wrocławskiego.

Jędrzejczak, G. and Sterniczuk, H. (2017). Nowa Ekonomia Strukturalna a polskie wyzwania rozwojowe. In: J.Y. Lin, A.Z. Nowak (eds.), Nowa Ekonomia Strukturalna wobec krajów mniej zaawansowanych. Warszawa: Wydawnictwo Naukowe Wydziału Zarządzania Uniwersytetu Warszawskiego.

Kharas, H. (2017). The Unprecedented Expansion of the Global Middle Class. Global Economy \& Development, Working Paper, 100, February. Washington, DC: The Brookings Institution.

Lustig, N., Lopez-Calva, L.F. and Ortiz-Juarez, E. (2013). Deconstructing the Decline in Inequality in Latin America. Policy Research Working Paper, No. 6552. Washington, DC: World Bank. Acquired from: https://openknowledge.worldbank.org/handle/10986/15915.

Manning, N., Mukherjee, R. and Gokcekus, O. (2000). Public Officials and Their Institutional Environment: An Analytical Model for Assessing the Impact of Institutional Change on Public Sector Performance. Policy Research Working Paper, No. 2427. Washington, DC: World Bank. Acquired from: https://openknowledge.worldbank.org/handle/10986/19797.

Mazzucato, M. (2013). The Entrepreneurial State Debunking Public vs. Private Sector Myths. London-New York-Delhi: Anthem Press.

Mracek, K. (2012). Middle-Class Spenders Will Lead Global Growth. Washington, DC: Kiplinger Washington Editors Inc. Acquired from: https://www.kiplinger.com/article/ business/T019-C021-S001-middle-class-spenders-will-lead-global-growth.html.

Nipperdey, Th. (1998). Deutsche Geschichte 1800-1866. Bürgerwelt und starker Staat. Munich: Verlag C.H. Beck.

PARP. (2017). Raport o stanie sektora małych i średnich przedsiębiorstw w Polsce 2017. Warszawa: PARP. Aquired from: parp.gov.pl/images/PARP_publications/pdf/raport $\% 20$ o\%20stanie $\% 20$ sektora $\% 20 \mathrm{msp} \% 20 \mathrm{w} \% 20$ polsce_2017.pdf.

12 Księga Przysłów, 16,18, przekład Biblia Tysiąclecia. 
Rosenstein-Rodan, P. (1943). Problems of Industrialization of Eastern and South- Eastern Europe. Economic Journal, 53(210/211), pp. 202-11.

Struktura sektora przedsiębiorstw w Polsce na tle krajów UE. (2018). Ernst and Young. Acquired from: https://www.ey.com/Publication/vwLUAssets/ey-raport-polskieprzedsiebiorstwa-2017-02-mikrofirmy/\$FILE/ey-raport-polskie-przedsiebiorstwa-201702-mikrofirmy.pdf.

Szarzec, K. (2016). Przedsiębiorstwa państwowe w krajach Europy Środkowo-Wschodniej. Studia Ekonomiczne Uniwersytet Ekonomiczny w Katowicach, 260, 125-136.

U.S. Bureau of Labor Statistics. (2018). Real GDP per capita in the Republic of Korea (South Korea) (DISCONTINUED) [KORRGDPC], August 31. FRED, Federal Reserve Bank of St. Louis. Acquired from: https://fred.stlouisfed.org/series/KORRGDPC.

World Bank. (2008). Public sector reform: what works and why? An IEG evaluation of World Bank support (English). Washington, DC: World Bank. Acquired from: http://documents. worldbank.org/curated/en/311251468150314338/Public-sector-reform-what-works-andwhy-An-IEG-evaluation-of-World-Bank-support. 